\title{
Effects of Parental Influence on Adolescents' Career Choice in Badagry Local Government Area of Lagos State, Nigeria
}

\author{
Olaosebikan, Olusola Isaac; Olusakin, AyokaMopelola \\ Department of Educational Foundations, Faculty of Education, University of Lagos, Akoka, Nigeria.
}

\begin{abstract}
The purpose of this study was to investigate the effects of parental influence on adolescents' career choice on secondary schools students in Badagry Local Government Area of Lagos State. The sample consisted of three hundred respondents who were randomly selected from ten purposely selected secondary schools (3 Model Colleges, 4 Non-Model Colleges, and 3 Private Colleges). The instrument used was a questionnaire which was administered to the respondents personally by the researcher. Five (5) null hypotheses were formulated and tested. Chi-square, using analysis of contingency table was used to test the hypotheses. All hypotheses were tested at the 0.05 level of significance of variable of sex, class of school, and type of school as to the effects of parental influence on adolescents' career choice on secondary schools students in the Local Government Area. The findings of the study showed that $48.36 \%$ of the respondents agreed to parents influencing their career choice. On the average, $21.5 \%$ of the respondents agreed that their parents' line of business influenced their career choice, while $78.5 \%$ disagreed. On the whole, 30\% of the respondents agreed that they chose the family career because they need to sustain the family business. In addition, three (3) out of the five (5) null hypotheses tested were accepted because there were no significant differences in the variables compared. These were hypotheses 1, 3, and 5. Hypotheses 2 and 4 were rejected as there were significant differences in the variables compared. The results of these findings seem to indicate that adolescents in secondary schools in Badagry Local Government Area of Lagos State have some form of independence in making career choices.
\end{abstract}

Keywords:Adolescents; Career; Career choice; Parents; Secondary Schools Students; Parental Influence.

\section{Introduction}

Career may be defined as the progress and actions taken by a person throughout a lifetime, specially related to that person's occupations. A career is often composed of the jobs held, titles earned and work accomplished over a long period of time, rather than just referring to one's position (Business Dictionary.com). Dictionary com defines career as an occupation or profession, especially one requiring special training, followed as one's lifework. It also defines career as a person's progress or general course of action through a phase of life, as in some profession or undertaking. Career could also be defined as the sum total of life experiences including paid and unpaid work, community, volunteer and family activities. Microsoft Encarta defines career as somebody's progress in a chosen profession or during that person's working life, or the general path of progress taken by somebody.

Choosing a career is an extremely important decision that impacts an individual's entire future. Career exploration is defined as the extent to which possible careers are researched and considered. Research, Navin (2009) has suggested that exploring career options before committing to a career increases future career success and satisfaction. Thus, variables that influence career exploration in adolescents should be identified and acknowledged.

Sociologists stress the forces in our society as the major determinants of vocational choice. Some sociologists consider the birth right of the individual as a most significant factor in career choice since it establishes the family, race, nationality, social class, residential district, and to a large extent the educational and cultural opportunities for the person. Sociologists argue that the range of occupations that an individual will consider in choosing a career is determined largely by the status expectations of the social class to which he belong(Friesen, 1981). Similarly, parents strongly influence their children in the choice of a career. In some cases, according to Friesen, children inherit their father's occupations (i.e., farmer's sons). In others, the children choose an occupation within the range acceptable to parental values, expectations and social class. In addition, educational opportunities clearly influence vocational choice. For example, students who drop out of high school restrict their occupational choices to manual work or in many cases to insecure white collar jobs, or the semi-skilled and unskilled service or clerical occupations.

The psychologist, in comparison to the sociologist, is interested in the inner world of the individual and the role personality plays in vocational choice. According to Friesen (1981) the psychologist believes that the career a person chooses is an expression of the personality of life style of the individual. Thus personality theory is particularly important in vocational counselling. Several theories of personality such as psychoanalytic, 
trait, self and developmental theories will be briefly discussed as follows:Trait theory, Friesen stated attempts to understand the person in relationship to his personal characteristics or traits which are considered to be behaviour manifestations of the individual. A person can be described as articulate, bright, dull, loving, sensitive, open, closed, extroverted, introverted, neurotic or psychotic. According to Friesen, the assumption of trait theory is that people differ in their personal characteristics and jobs differ in their requirements. Counselling is then an attempt to match traits with jobs. The counsellor administers tests to clients and on the basis of the results of these tests and other information such as interview data, references and past performance, a matching process is undertaken. This method according to Friesen is also used in the educational admission process, and in the high school, university and employment service where matching the individual qualities with educational opportunities and jobs is taken for granted and practiced indiscriminately.

Structural theorists are personality theorists who view human personality as a structured whole with distinctive attributes. These attributes are organized in a unique manner and are characteristic of the individual. Friesen (1981) reviewed some structural theories which are identified as follows:

(a) Psychoanalytic Theory: Psychoanalytic theorists view vocational choice as an expression of the personality of the individual. Such concepts as identification, the development of defense mechanisms, sublimation and unconscious drives can be used to explain vocational choice.

(b) Self-Concept Theory: Self theorists, according to Friesen assume that vocational choice is an attempt by the person to implement his self-concept. The self is defined as a differentiated part of the total phenomenal field or it is the awareness one has of one's being. It is argued by self-theorists that in the job as well as in life generally, the person attempts to express his sense of who he is. He attempts to live out in his job his values, hopes, dreams and aspirations. The degree to which he can express who he is, according to Friesen, is related to the degree of job satisfaction a person obtains from his job. If the job is congruent with his conception of who he is as a person, the individual will have a high job satisfaction. On the other hand, if the job involves activities which are inconsistent with his sense of self, the person will have low job satisfaction.

(c) Need Theory: Need theorists propose that personal needs, whether at the conscious or unconscious level, are the major determinants of vocation choice. The need hierarchy theory of Maslow is of particular interest to vocational counsellors.

Developmental theorists Friesen (1981) believe that vocational choice is not only an expression of the total personality, but also that it occurs over a developmental sequence. Vocational choice is not a single event but should be viewed longitudinally. Accordingly, Friesen quoting some theorists such as Super, proposed four life stages, namely growth, exploration, establishment and decline. The exploration phase which characteristically occurs during high school and college is a period where the person explores various vocational alternatives and finally decides on a life's work. There are underlying factors which influence adolescents' career choice and which have in the last half century become of growing interest to educators, counsellors, ministers, and social scientists. Some people maintain that the individual does not exercise career choice, but that the social and economic environment determines the vocational choices that are made (Friesen, 1981). According to Friesen, it is argued that the individual does not exert a choice and that a person may make a wise and fulfilling career choice or an unsatisfying choice.

Parental attachment Navin (2009) has been shown to be positively correlated with career exploration. Navin found that parental attachment, defined as the extent to which one feels emotionally close to and supported by one's parents, was positively related to career exploration.. Similarly, according to Navin (2009), Lee and Hughey (2001) found that parental attachment was positively correlated with career maturity, which is defined, as how prepared an adolescent is to make career decisions. Though career maturity may not be synonymous with career exploration, career exploration is a necessary step in the process of gaining career maturity. According to Navin, parental attachment is important for self-efficacy, defined as how confident an individual is that he/she will be good at his/her future career. Effective career exploration is necessary to facilitate feelings of career self-efficacy. This study also lends support to the idea that parental attachment is important for career exploration. Some researchers have suggested that the reason for the relationship between parental attachment and various aspects of career development is that a secure attachment to one's parents provides a safe place for one to go for emotional support (Navin, 2009).

Career exploration requires that an individual actively seek out information from various professionals such as counsellors. This type of behaviour has the potential to be scary or stressful for a young adult. Thus, the security of parental attachment is important in that they help the individual feel emotionally supported and protected. 
Navin (2009) wrote that dating is another variable that may have an effect on career exploration of an adolescent. The amount of time a young adult spends dating in the college years may affect his/her career exploration. Dating refers to spending time in a relationship that an individual considers to be intimate and committed. However, while high parental attachment seems to increase amount of career exploration, quantity of time spent dating may decrease amount of career exploration.

Parents want their children to be successful in life. They hope to one day see them in satisfying careers with the promise of growth. The thought of seeing their children in dead-end jobs may be saddening. Parents wonder, though, if there is anything they can do to help ensure that the children are successful. Families, parents and guardians in particular (Taylor, Harris, \& Taylor. 2004), play a significant role in the occupational aspirations and career goal development of their children. Without parental approval or support, students and young adults are often reluctant to pursue, or even explore diverse career possibilities. Although parents acknowledge their role and attempt to support the career development of their children, parental messages contain an underlying message of "don't make the same mistakes that I did". These interactions may influence adolescents and young adults to select specific collegiate majors or pursue particular occupations.Many important career decisions, such as whether to attend college, university or a trade school, or a polytechnic, or enter the job force directly after secondary school are made during adolescence. These early decisions affect the rest of a person's life; therefore, it is important to understand the individual and social factors that play into the process of adolescent career development.

Numerous studies (Knowles, 1998; Marjoribanks, 1997; Mau \&Bikos, 2000; Smith, 1991; Wilson and Wilson, 1992) have found that college students and young adults cite parents as an important influence on their choice of career. Yet parents may not be unaware of the influence they have on the career development and vocational choice of their children. The adolescents or the young adults are in most cases at the mercy of their parents. In most times, it is a period of identity crisis. Their meats are cut, laces tied, and make sure that they have wiped or cleaned up after using the toilet. And yet at the same, we ask them one of the most important questions they will ever have to answer: what do you want to be when you grow up? Cradled between fingerpainting and applying for university, adolescence is a critical period during which individuals discover who they are and how they might like to earn a living. Students have shown, (About Kids Health, 2009) that job interests and aspirations formed in adolescence influence career choices made in adulthood. However, adolescents are vulnerable to environmental influence including peers, media, culture, and especially parents and family.

However, the career development process of an individual begins long before adult years. McDaniel and Hummel (1984) discussed the career development process in terms of three phases: awareness (before age 11), exploration (ages 11 to 17), and preparation (age 17 to young adulthood). In her study of the family-career connection, Miller (1984) discusses career development in terms of a process beginning in the preschool years and reviews the effects of parents as role models in the career decisions of their sons and daughters.

The influence of family on occupational and attainment of adolescents has been a subject of great interest to vocational and career educators and researchers alike. As is evident from a literature review done by Otto and Call (1985), researchers in such diverse fields as child development, sociology, demography, and career development have long recognized that families play a major role in shaping their children's educational and career decisions. Only when career educators understand the nature and extent of the family's influence on employment and education can they develop effective strategies for helping parents help their children make appropriate and satisfying career choices.

The career choice process of young people can be compared to rocks in a polisher. "All kinds of people grind away at them...but, parents are the big rocks in the tumbler" (Otto, 1989). Parents serve as major influences in the lives of their children. According to a large body of research, family factors often influence career development and decision-making(Keller, 2004). Career counsellors and parents have been interested in understanding these influences for several decades. However, understanding the precise ways in which family impact career development has proven difficult because the constructs of family and career development are broad and because the association between these two constructs varies with age, Keller opined. The most important parent behaviours according to finding from the study of parental behaviours that influence adolescents' career development is that basic loving and supportive parent behaviours (such as parents telling adolescents they are interested in their opinions) seem to be more important for middle school students than specific career-related action behaviours (such as giving adolescents written material about specific careers). The multiple regression analyses Keller reported, revealed that when students feel supported and loved by their parents, they have more skill in thinking about careers and the world of work than when they do not feel supported and loved. The results also indicated that when students feel supported and loved by their parents, they have more confidence in their own ability to find career information and to choose a career that would be interesting and exciting to them. This is important because other research shows that adolescents who feel efficacious regarding career decision-making tend to make more satisfying career choices later in life. 
The study in Keller's report showed that several parenting behaviours seem to be especially important for middle school students. The logistic regression revealed that five perceived parenting behaviours discriminate between adolescents with high and low career maturity and decision-making self-efficacy scores. According to the results, Keller (2004) advised; if parents want to enhance the career development of their young adolescents, they should try to do the following:

Express interest in various teenage issues that are important to their children.

- Tell their children they have high expectations for their career.

- Encourage their children to make their own decisions.

- Tell their children they are proud of them.

- Help their children understand the results from career tests or interest assessments they have taken.

The results of the study according to Keller (2004) also showed that middle school students and their parents have significantly different views about family relationships and parent behaviours. Furthermore, the partial correlation analyses revealed that students whose views about family relationships were very dissimilar from their parents' views had low levels of career decision-making self-efficacy. To put it another way, when middle school students and their parents are 'in tune' with each other about family issues, the students have more confidence in their ability to make good career decisions. This indicates that, in addition to support and love, communication and honesty between young adolescents and their parents may be important for the career development of the adolescents Keller concluded.

Hairston (2000) stated that of the factors that influence career choice processes, family members, particularly parents, are the most influential determinant of career plans, occupational aspirations, and occupational expectations. This is also supported by Otto when he asserted that even if schools had the resources with which to meet young people's career guidance needs, neither teachers nor counsellors can replace the influence parents have on their sons and daughters' career plans.

Agreeing with Hines et al., of the many factors that contribute to career choice, parents and family are one of the most influential. Mark Franklin, a career counsellor comments "[parents] say what is a good career and what is a bad career". "By the time parents figure out what the world is about, they think about job security, financial security, and prestige-particularly prestige," says Franklin. These values ultimately resurface when children begin considering career options. Adolescent girls may be particularly vulnerable, compared to their male peers. Girls are likely to change their goals to suit their parents' wishes.

Parental guidance style, Soundar (2005) is how often the child is prompted rather than told what to do, where the parent provides more information by:

- Being aware of their emotions, attitudes, likes and dislikes.

- $\quad$ Listening empathetically and validating their feelings and inclinations.

- Helping to label verbally and explore preferences.

- $\quad$ Setting limits while helping them to solve problems.

Although educational researchers and theorists agree on the positive effects of parental support in the educational and career development processes of African American adolescents, little is known about the underlying mechanisms of parental influence or how these mechanisms affect African American adolescents' pursuit of their educational and career-related goals. Free Online Library (2009) cited Bandura's (1977) proposed theory to help us understand how parents can successfully support their adolescents' educational and vocational development. According to Bandura, adolescents tend to pursue those activities for which they are most efficacious (i.e., self-confident). For example, adolescents who are efficacious about their abilities to successfully pursue their educational development and broaden their vocational options are more likely to engage in tasks related to those pursuits. Self-efficacy, Bandura stated, is a learned behaviour that is predicted by adolescents' responses to four sources of experiential learning: (a) personal performance accomplishments, (b) vicarious learning (modelling by significant others), (c) the emotional support of others, and (d) others' verbal encouragement. The development of adolescents' self-efficacy leads to their choice of academic and career-related pursuits, their persistence toward successfully accomplishing these pursuits, and their successful performance of these pursuits (Bandura, 1999; Bandura, Barbaranelli, Caprata, \&Pastorelli, 2001). Agreeing with Bandura, Turner and Lapan (2002) argue that for young adolescents, parents are the most salient providers of self-efficacy information.

Generally, (Hairston, 2000) parents' career aspirations aid children in selecting occupational goals, influence their knowledge of occupations, and familiarize them with occupational roles and requirements. Whether the child internalizes those aspirations is greatly determined by numerous values found within the home. Lee, (1984) also agreed that the occupational orientations of parents familiarize children with 
occupational roles, while the value orientations of parents provide the learning environment that motivates the aspirations of children.

In a study on how parents influence African American students' decisions to prepare for vocational teaching careers, the analysis of the literature clearly identified mothers as the most influential parent (Bracey, 1992; Dawkins, 1989; Fields, 1981; Simpson, 1996). Hairston, (2000) reporting the findings of (Bracey, 1992; King, 1993; Simpson, 1996) in early adulthood, many African American children, particularly African American females are influenced by the aspirations of their mothers. The employment status of mothers, as well as the mother-child relationship influences the vocational outcomes of African American children (Bracey, 1992). African American mothers influence their children by establishing middle class values of hard work and responsibility, placing emphasis on education, maintaining high expectations, and introducing cultural values (Simpson, 1996). This goes along with Schulenberg, Vondracek, and Cronter(1984) findings that fathers play more of a complimentary role in career decision-making.

Another parental factor that influences adolescents' career choice is the desire to imitate parents' altruistic behaviour and role as community contributors. In his report, Hairston wrote that adolescents who took up vocation in teaching revealed that their parents' roles as community contributors influenced their desires to give to others through the general career of teaching, as well as through the specific teaching concentration of vocational education. Consistent references to parents' community contributions through work, church, social, and civic organizations highlighted the impact of these contributions. Like their parents, respondents were eager to make notable contributions to the community by becoming vocational teachers. As students acknowledged the altruistic nature of parents, they appeared to tap into their personal desires of benevolence. Hairston wrote that respondents acknowledge their parents' roles as helpers then cited their personal desires to help children through learning.

High Academic and Career Expectations by Parents: This theme derived from parental expectations regarding educational endeavours, academic achievement, and career goal success. Respondents consistently recalled parents pushing them to earn outstanding grades as opposed to being content with average grades. Expectations of academic achievement affected respondent's perceptions of their vocational teaching career goal (Hairston, 2000). Furthermore, expectations of outstanding grades made respondents set high personal expectations during the teacher preparation process. Because parents expected them to excel during vocational teacher preparation, they diligently worked to achieve the career goal of vocational teaching. An agricultural education student recalled how his father pushed him to achieve academic success and discussed how it affected his attitude to achieve as he prepared for a vocational teaching career:

Many African American parents engage in positive racial socialization with their children and emphasize the importance of hard work, a good education, and racial pride for survival in society. Because of high academic expectations, respondents displayed determination to excel during the vocational teacher preparation process. Respondents believed that their parents viewed academic success as key to occupational success and perceived academic success as increasing their chances of successfully becoming vocational teachers (Sanders, 1997).

Parental Support in Academic and Occupational Endeavours: All respondents in the study Hairston (2000) indicated a sense of parental support for their vocational teaching career choice-support that strongly encouraged them to seek and complete pursuits in the field of vocational teaching. According to Hairston, respondents indicated that career choice apprehensions were eased when parents approved of their decisions to prepare for vocational teaching careers. Furthermore, parental support indicated career choice approval and elicited expressions of pride among respondents as they witnessed their parents' esteem for vocational teaching. Parental support was additionally motivating when parents showed interest, support, and involvement in respondents' vocational student organization activities.

According to Hairston, mothers were cited as particularly influential because they provided support that eased respondents' apprehensions about vocational teacher preparation. This finding, in reference to (Bracey, 1992; Dawkins, 1989; Fields, 1981; Simpson, 1996) by Hairston adds to myriad literature citing the strong influence of mothers on the career choice of children. Parents Providing Early Exposure to Vocational Subject Matter and/or the Teaching Field: According to Hairston (2000) it became initially evident that exposure to the field of teaching in general often related to preparing for vocational teaching specifically. Thus, this theme was based on teaching-related and/or vocationally-related experiences gained during childhood. Vocationallyrelated experiences are those that can be associated with specific vocational concentrations.

Hairston noted that respondents with parent educators were strongly influenced to enter teaching. Their parents helped them gain an understanding of the field through direct, frequent, and early exposure to the profession. At a young age, respondents developed an understanding of the duties, responsibilities, and lifestyles of a teacher and eventually began to consider teaching. One respondent preparing to become a marketing teacher explained, "...just hanging out around my mother's school, just getting a feel for what teachers do, I liked it... That whole background and involvement made me kind of interested in teaching." The study according to 
Hairston revealed that respondents were introduced to vocationally-related experiences during early ages. All respondents entered the specific vocational concentration they associated with the experiences they shared with parents during childhood. They remembered the first childhood experience with a parent, the first childhood responsibility obtained from a parent, or the first toy purchased by a parent that created initial interests in vocational subject areas.

Hairston (2000) noted that the simultaneous introduction by parents to vocationally-related activities and to the general career of teaching was extremely influential. Herein lies the link between the choice of the general field of teaching and the choice of vocational teaching specifically. The notion of being surrounded by the teaching profession intermingled with exposure to vocational activities, lead respondents to an understanding of teaching as well as to an understanding of vocational content. King (1993) found that early discussion about teaching as a career choice was one of the most influential factors affecting a career choice of teaching. King indicated, "The more familiar an individual is with the requirements and rewards of the work world, the better equipped they are to make a career choice".

Parents Aiding in Discovery of Aptitudes and Interests Related to Vocational Subject Matter: In his findings, Hairston (2000) reported that respondents were strongly influenced to teach vocational subjects when parents encouraged pursuits of activities associated with vocational concentrations. From there, students began to discover aptitudes for technical areas within specific vocational concentrations. Respondents who discovered strengths and interests in the hands-on aspects of vocational subject matter with their parents were interested in continuing those interests later in life. A technology education student recalled how his grandfather (his parental caretaker) influenced his decision to focus on the specific concentration of technology education by providing access to technology based activities.

According to Hairston, the implications of this study are that parents or parental caretakers helped develop interests in vocational teaching careers and specific vocational concentrations. Parents accomplished this by serving as role models who enhanced the altruistic desires of respondents, supported respondents' decisions to pursue vocational teaching careers, set high achievement goals that would allow respondents to complete the teacher preparation process, and introduced the positive aspects of teaching and vocational subject matter at a young age. Additionally, Hairston added, parents involved children in hands-on learning experiences, provided opportunities that nurtured interests in vocational subject matter, and created environments that nurtured the discovery of aptitudes for vocational content.

The findings above are in congruence with McConnell's discovery (1997) that parents influence the development of their children in many ways, but added that their role in career planning activities is not well defined. He opined that parents are clearly concerned about future careers for their children and how they can best contribute. Their in-depth knowledge of their child is a valuable and essential resource for education and rehabilitation professionals, McConnell concluded.

Family background: Other family variables that have been shown to influence career aspirations include the parents' occupation (Trice, 1991) and family size (Downey, 1995; Marjoribanks, 1986; Schulenberg, Vondracek, and Croutter, 1984; Singh, et al., 1995). The father's occupational status is highly correlated with his son's occupation (Blau, 1992; Blau and Duncan, 1967; Conroy, 1997). Family size also appears to influence adolescent career aspirations because parents with large families tend to have less money to aid the older children in attending college, while younger children may receive more financial assistance since the financial strain is less once the older children leave home (Schulenberg, et al., 1984).Family background factors also found to be associated with career development, and in congruence with Downey, et al. include parents' socioeconomic status (SES), their educational level, and biogenetic factors such as physical size, gender, ability, and temperament" (Penick\&Jepsen 1992). In a study of the influences on adolescents' vocational development reported by Mortimer et al. (1992), the variable that had the most effect on educational plans and occupational aspirations was parental education. Mortimer et al. also report that parents with postsecondary education tend to pass along its importance to their children. Montgomery (1992) notes that females talented in mathematics viewed their career choices as reflective of interests that stemmed from early family influence and educational opportunities. Marso and Pigge (1994) found that the presence of teachers in the family was a significant factor influencing teacher candidates' decisions to teach. DeRidder (1990), however, points out that lower levels of parent education can retard adolescents' career development. "Being born to parents with limited education and income reduces the likelihood of going to college or achieving a professional occupational goal and essentially predetermines the child's likely vocational choice".

Family income is another aspect of family background that influences the career development of youth, especially for girls (Mortimer et al. 1992). One reason for this may be that families with limited economic resources tend to direct them first to the males of the family, giving less hope and encouragement for further education to the daughters in the family. Also, some parents, especially working class or lower-income parents may hold values that place girls in the homemaker role and reflect less emphasis on occupational 
preparation. Given this disposition, it is understandable that the self-efficacy of girls with respect to career opportunities is linked to the economic support they can expect to receive from their parents.

Yet, in other studies Taylor, Harris, and Taylor (2004) each of these family variables has also been found to be insignificant in influencing aspirations. Nevertheless, families appear to influence, at least to some extent, career aspirations of adolescents and young adults. If these family factors are influential in career decision making, then it becomes difficult to explain how an impoverished student from a broken home can go on to become a wealthy, financially successful worker. As the paradigm of research shifts, it becomes clear that family interactions are just as important as physical descriptors (Taylor, et al., 2004).

Parent-Child Interactions: Since the mid-fifties, research has suggested that family interaction is linked to occupational behaviour. It is even believed that possibly the notion of family interaction or functioning-incorporating parenting style (authoritarian or passive), level of support, guidance, and responsiveness - may have more influence on career development than demographics, including educational aspirations of parents (Taylor et al., 2004).Parental support and encouragement are factors that have been found to influence vocational outcome. For instance, the attitudes and behaviours that children adopt toward work may be the result of what parents say. Parents convey their influence to children through interactions such as conversations and through their reactions (both verbal and nonverbal). This then affects what children think, say, and perceive about various careers.

Often there is a contradiction between what parents say to young adults and what they ask of them. For instance, a parent may comment that it is acceptable to pursue a position with a nonprofit agency, but then counter such statements with comments about low pay and long hours. These types of references imply that it's more important to earn a high salary than to pursue a satisfying position. Parents may also become overly involved in career decisions because they want their child to be more content in a career than they are in their own jobs. Children may begin to identify and accept what parents say in order to please them. Therefore, they take their parents' comments as absolute and neglect to challenge them or to assess their validity. Although parenting styles may differ, parents tend to want to do what is best for their children, and children generally pay attention to what is said by their parents. Thus, children are affected. This is what Lankard (1995) viewed as family processes. According to her, the investigation of family processes viewed in relation to life roles offers additional insight into the influences of the family. Family processes of interaction, communication, and behaviour influence what the child learns about work and work experiences. Attitudes about school and work, educational and career goals and aspirations, and values have a long-term impact on a youth's career choices, decisions, and plans. "Parents as daily models provide cultural standards, attitudes, and expectations and, in many ways, determine the eventual adequacy of self-acceptance and confidence, of social skills and of sex roles. This also agrees withDeRidder (1990)"The attitudes and behaviours of parents while working or discussing their work is what the children respond to and learn."

Through the process of educating their children about life roles, parents can influence the employability skills and values that children subsequently adopt. Grinstad and Way (1993) report one mother's message to her daughter on the theme of becoming self-sufficient: "You have to have a way to take care of your family; you cannot depend on a man. You have to think about number one and that's you. How are you going to make a living, how are you going to support your children, if you don't have some kind of training?" The interaction of many individual variables in family process is a significant factor to consider in studying family influence on career development. Middleton and Loughead (1993) suggest that adolescents' career aspirations be examined from an interactionist perspective rather than a unilateral process of influence, "focusing on the context and situations in which adolescents' career development occurs"

Consistent with previous findings, (Taylor, et al. 2004) parents perceive themselves as the most influential figures in their children's' career development and decisions. Parents overwhelmingly ranked themselves as the most influential people. The only other groups mentioned fairly consistently were teachers, followed by counsellors. Therefore, it appears as if parents recognize their role in the career decision-making process. They may also have felt obligated to list themselves high and rank others lower because it may be disheartening to a parent to think that they are not influential in their children's development. Although they perceive themselves to have minimal influence on adolescent career decision-making, they, nevertheless, view themselves as being more influential than any other individual. They may be interpreting career choice as simply a process of trial and error that their children need to experience for themselves.

When students become curious about pursuing a particular field of study or career plan, parents who feel that they should not interfere may appear aloof to their children, causing miscommunication between the two parties. This passivity may result from a lack of knowledge about careers, a desire to instill independence in their children, or a fear of becoming dictatorial (particularly if a child is not content with the parents' choice). Regardless of their motives, parents need to be aware of their role in career development, since previous research (Taylor, et al. 2004) indicates that they have the most influential role. If parents do not feel comfortable 
discussing various careers with their children, it may be easier to do nothing or say that they don't have any influence.

The role and influence of parents as partners in career planning of their children is however described by (Anderson,1992; Demo, Small,\&Savin-Williams, 1987; Grotevant\& Cooper, 1983) when they said that adolescents' self-esteem and ability to make decisions are related directly to the quality of parent-adolescent communication; as high school students have cited their parents as offering more assistance in career planning than teachers, counsellors or peers (Davies \&Kandel, 1981; Noeth, Engen, \&Noeth, 1984; Dowdy, Carter,\& Smith, 1980). Even though parents are influential in the career development process of their children, and they often wish to be included, yet a specific role for parents is often not defined (McNair \&Rusch, 1987). But in all these, a career crisis may develop when there is a mismatch in terms of the ego strength of the child and the environmental pressures that challenge their identity. Adolescents straddle the line of childhood obedience and adult independence. In a sense, they are learning how to make up their own minds, perhaps ignoring what they are told (About Kids Health News, 2007).

However, Middleton and Loughead (1993) present three categories to describe types of parental involvement in adolescents' career development: (1) positive involvement, (2) non-involvement, and (3) negative involvement. The greatest anxiety adolescents feel about their career decisions or exploration, quite understandably, is in response to parents' negative involvement. Parents in the "negative involvement" category are often controlling and domineering in their interactions with their children. The children of such parents often pursue the careers selected by their parents rather than those they desire so as not to disappoint their parents or go against their wishes. Likewise, they feel a strong sense of frustration and guilt when they do not meet their parents' expectations.

The burden of following a parent's narrowly defined expectations of success has resulted in "mental health problems, estranged parent-child relationships, or in socially delinquent behaviours"). Penick and Jepsen (1992) note that "adolescents from enmeshed families may have difficulty mastering career development tasks because they are unable to distinguish their own from parental goals and expectations". Disengagement of family and adolescents has similarly negative effects. "Adolescents from disengaged families may lack familial support and interaction, resulting in limits on self-knowledge and task orientation that interferes with mastery of career development tasks".

Peer pressure and societal labelling: Peer pressure and societal labelling are factors that have been discovered to influence adolescents' career choice. In a study carried out in a polytechnic in Zimbabwe, Matope and Makotose, (2007) it appeared that peer pressure, generally, did not significantly influence female students towards choosing engineering as a career. However they cited Giddens (1993) who argues that "peer-group socialization tends to play a major part in reinforcing and further shaping gender identity throughout a child's school career." It may therefore not be ruled out that peer pressure is a factor influencing female students' career choice because the researchers were not unanimous on its influence.

It could be said that the society had changed its attitude towards some professions as fields suited for males only. There seemed to be an awareness that females could also venture into those fields and perform significantly just as their male counterparts. However, in the Zimbabwean study, it was still evident that some societal elements believed that females could not study engineering. This could be attributed to the fact that the Zimbabwean society is a patriarchal one which traditionally considered engineering to be a males' domain Matope, and Makotose, (2007). From the Marxist perspective, a patriarchal society would have all females do all the domestic work to the benefit of the males who are considered as bread winners.

Government laws and regulations: Stewart (1981) says that "many laws tend to favour men" in the working place. The introduction of laws which necessitated equal pay to both males and females, removal of discrimination of sex when it comes to engineering jobs and fully paid maternity leave made the engineering field attractive to females Matope and Makotose, (2007). Nevertheless, the study in Zimbabwe established that the Zimbabwean government has gone a long way in encouraging females to enter the engineering field; and there was a general consensus that the government should continue improving its support for females in engineering fields.

Employers' attitudes and employment conditions: The attitudes displayed by employers; and employment conditions in work places, and especially concerning some professions (Matope\&Makotose, 2008) could either lure adolescents or repel them. Conditions that are gender bias could also attract the favoured and distract the unfavoured gender. In their report citing Zimbabwe, most employers were giving the same pay for both males and females for the same jobs. However, there was still the need of improving the working environment further to make the work place more comfortable for female employees. This could be done by providing baby seating facilities to working mothers, time allowances to sucking mothers, extension of the maternity leave period, and affording females equal promotion prospect as those of males; without compromising productivity. Matope and Makotose noted that the reflections of the Zimbabwean patriarchal 
society were rampant in the educational such that most females considered engineering to be a males' field, hence the low enrolment of the female engineering students.

From the review of relevant literature, researchers have attempted to understand the variables that influence students' occupational goals (family, level of parental education, school, peers, personality, and socioeconomic status). There are significant family influence factors that affect a child's career and educational decisions. These significant factors are: (1) geographic location, (2) genetic inheritance, (3) family background, (4) socioeconomic status, (5) family composition, (6) parenting style, and (7) parent-work related attitudes. Splete and Freeman-George (1985) regard the first-four factors as having a strong influence on a child's physical and mental abilities, educational, and employment opportunities, and financial resources, the last three have a profound effect on a child's personality type, preference for certain types of interpersonal relationships, work attitudes, and willingness to pursue a non-traditional career.

Other family variables that have been shown to influence career aspirations include the parents' occupation (Downey, 1995); Majoribanks, 1996; Schulenberg, Vondracek, and Croutter, 1984; Singh et al., 1995). The father's occupational status is highly correlated with his son's occupation (Blau, 1992; Blau and Duncan, 1967; Conroy, 1997). Family size also appears to influence adolescent career aspirations because parents with large families tend to have less money to aid the older children in attending higher institution, while younger children may receive more financial assistance since the financial strain is less once the older children leave home.(Schulenberg, et al., 1984) .

Contrariwise, studies (Boatwright, Ching, and Parr, 1992; Mau and Bikos, 2000), have found each of these family variables to be insignificant in influencing aspirations. Nevertheless, families appear to influence, at least to some extent, career aspirations of adolescents and young adults. If these family factors are influential in career decision making, then it becomes difficult to explain how an impoverished student from a broken home can go on to become a wealthy, financially successful worker. As the paradigm of research shifts, it becomes clear that family interactions are just as important as physical descriptors.

These findings, among others present enough evidences of effects of parental influence (overtly or covertly) on the career choice of adolescents. According to a large body of research, family factors often influence career development and decision-making (Keller, 2004). Career Counsellors and parents have been interested in understanding these influences for several decades. However, understanding the precise ways in which families impact career development has proven difficult because the constructs of family and career development are broad and because the association between these two constructs varies with age.

A research with nearly 300 middle school students and their parents conducted by Keller (2004) sheds more light on the complex interaction among family and career factors. The study was conducted to find out how specific parent behaviours positively and negatively influenced the career development of a sample of predominantly Caucasian young adolescents attending public schools in both rural and urban areas. Instruments used on the students include 50-question Career Maturity Inventory (Crites \&Savickas, 1995), the 12-question Middle School Career Decision-Making Self-Efficacy Scale (Fouad, Smith, \&Enochs, 1997), and a 30-question parent career behaviour checklist created and evaluated for use in the study. The students' parents also completed the Likert-Scale parent career behaviour measure. In the study, the regression and correlation analysis revealed that perceived parent behaviours were significantly related to the career maturity, and decision-making self-efficacy of the middle school students, after controlling for student gender and grade level. The finding from the study is that basic loving and supportive parent behaviours (such as parents telling adolescents they are interested in their opinions) seem to be more important for middle school students than specific career-related action behaviours (such as giving adolescents written material about specific careers). The multiple regression analyses revealed that when students feel supported and loved by their parents, they have more skill in thinking about careers and the world of work than when they do not feel supported and loved.The result also indicated that when students feel supported and loved by their parents, they have more confidence in their own ability to find career information and to choose a career that would be interesting and exciting to them. This is important because other research shows that adolescents who feel efficacious regarding career decision-making tend to make more satisfying career choices later in life.

As a result of all these, the effects of parental influence on adolescents' career choice on secondary schools students were worth researching into and this study limited itself to Badagry Local Government Area of Lagos State. It was done with the hope that the result of this study would provide clues to the extent parental influence on career choice of adolescents have affected them positively or negatively, and thereby provide bases for Guidance and Counselling through various recommendations to adolescents, parents, teachers, schools, and counsellors. The area of study is Badagry Local Government which is one of the twenty local governmentsin Lagos state as enshrined in the Constitution of the Federal Republic of Nigeria. The Local Government is bounded in the North by the boundary of Ogun state; South by Atlantic ocean; East by boundary with Olorunda Local Government at Igborosun hospital, French school, Administrative Staff College of Nigeria,(ASCON) 
down to Ajido; West by Badagry West Local Government. Badagry subsists largely on fishing and agriculture, and maintains a small museum of slavery.

\section{Research Hypotheses}

The following hypotheses were tested in the study:

1. Parental influence will not have significant effect on the career choice of adolescents.

2. There is no significant difference between students in government secondary schools, and students in private secondary schools regarding the effects of parental influence on adolescents' career choice.

3. There is no significant difference between students in Model Colleges and public colleges regarding the effects of parental influence on adolescents' career choice.

4. Parental attitude to work will not have significant effect on adolescents' career choice.

5. Perceptions of parental occupational satisfaction will not have a significant effect on career aspiration of adolescents.

\section{Research Design}

A descriptive survey research design was used for this study. The main purpose of this type of research is to describe the data and characteristics about what is being studied. The idea behind this this is to study frequencies, averages, and other statistical calculations. This was done with the believe that the interaction of the variables on each other has been completed before the researcher begins the research. According to Nwadinigwe (2002), the job of the researcher is just to consciously manipulate the variables. Data collection from respondents for this survey research was done using Likert-type questionnaire.

\section{Population Of The Study}

The study was conducted in Badagry Local Government area of Lagos State, Nigeria. The population of the study comprised of three hundred randomly selected adolescents in ten secondary schools in the Local Government. These secondary schools included public, model and private schools. The sampling technique used in this study is the probability sampling technique where every item in the population had equal chance of being included in the sample.

\section{Research Instruments}

A thirty item questionnaire designed by the researcher was used to elicit responses from the respondents. The questionnaire was divided into two sections: A and B. section A included the biodata of respondents which included gender (male or female), class in school, class of parents (educated or not educated), type of school (public, model or private). Section B consisted of a-thirty-item Likert-type questionnaire grouped into parts.

\section{Hypotheses testing}

\section{Data Analyses And Interpretation}

Hypothesis 1: Parental influence will not have significant effecton the career choice of adolescents.

Table 1: Result of chi-square analysis on significant effect of parental influence on adolescents by sex.

\begin{tabular}{|lllllll|}
\hline $\begin{array}{l}\text { Variable } \\
\mathrm{X}^{2} \mathrm{X}^{2}\end{array}$ & Agree Disagree Total & df & $\mathrm{P}$ & Cal Tab Decision \\
\hline Male73 & 77150 & 1 & 0.05 & 0.973 .84 & Not Significant & \\
\hline Female7080150 & & & & & & \\
\hline 143157 & 300 & & & & & \\
\hline
\end{tabular}

The Critical $x^{2}$ value for one degree of freedom and at 0.05 level of significance was 3.84 which is greater than the calculated $x^{2}$ of 0.97 , hence we accept the null hypothesis and reject the alternate hypothesis. It was therefore concluded that parental influence will not significantly affect the career choice of adolescents in Badagry Local Government.

Hypothesis 2: There is no significant difference between students in government secondary schools and students in private secondary schools regarding the effects of parental influence on adolescents' career choice.

Table 2:Result of chi-square Analysis on difference on effects of parental influence on adolescents' career choice between students in government secondary schools and students in private secondary schools by class of school.

\begin{tabular}{|c|c|c|}
\hline $\begin{array}{l}\text { Variable } \\
\mathrm{X}^{2} \mathrm{X}^{2}\end{array}$ & Agree Disagree & Total df P CalCritDecision \\
\hline
\end{tabular}




\begin{tabular}{|lcccccc|}
\hline Govt. Schools & 66 & 84150 & 1 & 0.05 & 20.61 & 3.84Significant \\
\hline Private Schools 46 & 104 & 150 & & \\
\hline Total & 112 & 188 & 300 & & \\
\hline
\end{tabular}

In testing the hypothesis, the critical $x^{2}$ value for one degree of freedom at 0.05 level of significance was 3.84 which is less than calculated $x^{2}$ at 20.61 , hence we reject the null hypothesis that there is no significant difference on effects of parental influence on adolescents' career choice between students in government secondary schools, and students in private secondary schools. What this means therefore, is that there is significant difference in effects of parental influence between adolescents in government secondary schools and adolescents in private secondary schools.

Hypothesis 3: There is no significant difference between students in Model Colleges and public colleges regarding the effects of parental influence on adolescents' career choice.

Table 3: Result of chi-square analysis on difference on effects of parental influence on adolescents' career choice between students in model colleges and public colleges by type of school.

\begin{tabular}{|lcccccccc|}
\hline $\begin{array}{l}\text { Variable } \\
\mathrm{X}^{2} \mathrm{X}^{2}\end{array}$ & Agree & Disagree & Total dfP & Cal & \multicolumn{2}{l|}{ CritDecision } \\
\hline Model Schools 63 & 87 & 150 & 1 & 0.05 & 0.69 & 3.84 & Not Significant \\
\hline Public Schools 67 & & 83 & 150 & & & & & \\
\hline Total & 130 & & 170 & 300 & & & & \\
\hline
\end{tabular}

Table 3: presents the results of the analysis of difference on parental influence on adolescents' career choice between students in Model Colleges and students in public colleges. The hypothesis was tested at 0.05 level of significance. The calculated $\mathrm{x}^{2}$ value was 0.69 , while the table $\mathrm{x}^{2}$ value was 3.84 . The result shows that there is no significant difference on effects of parental influence on adolescents' career choice between students in Model Colleges and public colleges, and so the null hypothesis was accepted.

Hypothesis 4: Parental attitude to work will not have significant effect on adolescents' career choice.

Table 4: Analysis of chi-square on effects of parental attitude to work on adolescents by type of school.

\begin{tabular}{|c|c|c|c|c|c|}
\hline \multicolumn{6}{|c|}{$\begin{array}{l}\text { Variable Agree Disagree Total dfP Cal Tab Decision } \\
\mathrm{X}^{2} \mathrm{X}^{2}\end{array}$} \\
\hline Model & 68 & 100 & & & \\
\hline Non-Model 3565 & 1002 & 0.05 & 12.34 & 5.99 & Significant \\
\hline Private & 80 & 100 & & & \\
\hline Total & 213 & 300 & & & \\
\hline
\end{tabular}

In testing the hypothesis, the $\mathrm{x}^{2}$ value for two degrees of freedom at 0.05 level of significance was 5.99 which is less than calculated $\mathrm{x}^{2}$ at 12.34 , hence we reject the null hypothesis that parental attitude to work will not have significant effect on adolescents' career choice in Badagry. This, in effect, is an indication that parental attitude to work will have effect on adolescents' career choice in Badagry.

Hypothesis 5:Perceptions of parental occupational satisfaction will not have a significant effect on career aspiration of adolescents.

Table 5: Result of chi-square analysis on effect of perceptions of parental occupational satisfaction on adolescents' career aspiration by sex.

\begin{tabular}{|c|c|c|c|c|c|c|c|c|}
\hline $\begin{array}{l}\text { Variable } \\
\mathrm{X}^{2} \mathrm{X}^{2}\end{array}$ & Agree & Disagree & Total & $\mathrm{dfP}$ & Cal. & Crit & Decision & \\
\hline Male & 49 & 101 & 150 & & & & & \\
\hline Female & 41 & 109 & 150 & 1 & 0.05 & 1.90 & 3.84 & Not Significant \\
\hline Total & 90 & 210 & 300 & & & & & \\
\hline
\end{tabular}

Table 5: presents the results of the analysis of significant positive effect of perceptions of parental satisfaction on adolescents' career aspiration. It shows that the calculated $\mathrm{x}^{2}$ at 1.90 is less than the table $\mathrm{x}^{2}$ at 3.84. The result shows that perceptions of parental occupational satisfaction will not have a significant positive effect on career aspiration of adolescents, and so the null hypothesis is accepted.

Two of the five null hypotheses tested were rejected, and they are hypotheses 2 and 4; while hypotheses 1, 3, and 5 were accepted. Hence from the analyses, it was found out that: 
(1) Parental influence will not have significant effect on the career choice of adolescents in Badagry Local Government.

(2) There is significant difference between students in government secondary schools and students in private secondary schools regarding the effects of parentalinfluence on adolescents' career choice.

(3) There is no significant difference between students in Model Colleges and public colleges regarding the effects of parental influence on adolescents' career choice.

(4) Parental attitude to work will have significant effect on adolescents' career choice in Badagry.

(5) Perceptions of parental occupational satisfaction will not have a significant effect on career aspiration of adolescents.

\section{Discussions}

The result of the findings indicated that parental influence will not have significant effect on adolescents' career choice, and that perceptions of parental occupational satisfaction will not have effect on career aspirations of adolescents based on the following intervening variables such as sex, and type of school. These findings are at variance with Dobbins (2000) when he asserted that parents' career aspirations aid children in selecting occupational goals, influence their knowledge of occupations, and familiarize them with occupational roles and requirements. Whether the child internalizes those aspirations is greatly determined by numerous values found within the home. The findings are also not in consonance with some people's opinion as cited by Friesen (1981) that the individual does not exercise career choice, but that the social and economic environment determines the vocational choices that are made. Others argue that the individual does exert a choice and that a person may make a wise and fulfilling career choice or an unsatisfying choice.

However, the findings also revealed that; parental influence will have negative effect on adolescents' career choice; there is significant effect of parental influence on adolescents' career choice; and that parental attitude to work will have significant effect on adolescents' career choice based on type of school. These results agree with sociologists' view that the range of occupations that an individual will consider in choosing a career is determined largely by the status expectations of the social class to which he belongs (Friesen, 1981). The implications of the sociologists' view for counselling according to Friesen is that the vocational choices people make are related to their social class, and the social origins of an individual limit the range of occupational opportunities available to the person. Students who come from lower class homes often find it difficult to continue their education while those from upper class homes obtain much encouragement from their families and peers to continue their studies. The findings also agree with McNair and Rusch, (1987) that parents are influential in the career development process, and they often wish to be included, yet, a specific role for parents is often not defined. In a situation where parental influence interferes with the career choice of adolescents, a career crisis may develop when there is a mismatch in terms of the ego strength of the child and the environmental pressures that challenge their identity. The adolescents straddle the line between childhood obedience and adult independence.

Whereas from this research, it is established that parental influence will not have significant effect on the career choice of adolescents in Badagry Local Government; a research with nearly three hundred middle school students in the United States by Keller, (2004) revealed otherwise. Also from the finding, factors that contributed to that were basic loving and supportive parent behaviours (such as parents telling adolescents they are interested in their opinions) seem to be more important than specific career - related action behaviours (such as giving adolescents written material about specific careers). The multiple regression analyses of the report revealed that when students feel supported and loved by their parents, they have more skill in thinking about careers and in the world of work than when they do not feel supported and loved. The results also indicated that when students feel supported and loved by their parents, they have more confidence in their own ability to find career information and to choose a career that would be interesting and exciting to them. This is important because other research shows that adolescents who feel efficacious regarding career decision-making tend to make more satisfying career choices later in life.

The implications for counselling on this are that if parents want to enhance the career development of their young adolescents, they should try to do the following:

- Express interest in various teenage issues that are important to their children.

- Tell their children they have high expectations for their career.

- Encourage their children to make their own decisions.

- Tell their children they are proud of them.

- Help their children understand the results from career tests or interest assessments they have taken.

In addition to the above, support and love, communication and honesty between the adolescents and their parents may also be important for the career development of the adolescents. 


\section{Recommendations}

Based on the findings of this study, the following recommendations are made:

1) Professional school counsellors should provide collaborative support and training to parents on career guidance. This is because their education, skills, and position within the school community, are in a unique position to assess the needs of adolescents, and the skills and stressors of their parents.

2) School counsellors can assist parents in learning how to provide emotional support by helping them understand the emotions that adolescents experience when faced with difficult educational and vocational challenges, by helping parents talk to their adolescents about what fun their future job could be.

3) Even though the research findings revealed that perceptions of parental occupational satisfaction will not have a significant positive effect on career aspiration of adolescents, school counsellors should encourage parents to share about their own excitement when considering their adolescents' future educational and career opportunities.

4) School counsellors should assist parents in providing career-related modelling for their adolescents by showing them how to talk to their adolescents about their own occupations as well as about other occupations that are available in the world of work.

5) Parents in Badagry should imbibe the development of basic work attitudes as promptness, respect, dedication, expression of positive regard to constituted authority, and responsibility. This is necessary considering the fact that their attitude to work will have significant effect on adolescents' career choice.

6) School counsellors in alliance with parents should provide opportunities that would nurture interests in vocational subject matter, and create environments that would nurture the discovery of aptitudes for vocational content.

7) Parents, generally, should be cautioned against imposing their own goals onto their children, they can act as a guide. This is because adolescents need to discover who they are on their own.

8) Parents should respect their adolescents' differences. Family environments that show respect for differences and independence would enormously be helpful to the child's career development.

9) Parents should show genuine interest in and support for their adolescents' career plans.

10) Parents should encourage their children to explore career options. This could be done through job shadowing, volunteering, and part - time jobs.

11) Parents should be mindful of careless comments they make about careers, and even of theirs. This is because children are susceptible to careless comments parents make about "good" and "bad" professions.

Beside all these, each secondary school student should be guided to have an idea of what he would want to become in life. Therefore, according to Olusakin and Ubangha (1996) students in consultation with their parents, class teacher, and school counsellor should plan for his future academic career.

\section{References}

[1]. Bandura, A. (1999). Social cognitive theory of personality. In Lawrence A. Pervin, \& Oliver E. John (Eds.), Handbook of personality: Theory and research (2nd ed) 154-196, New York; Guilford.

[2]. Bandura, A.,Barbaranelli, C., Vittorio Caprara, G., \&Pastorelli, C. (2001). Self-efficacy beliefs as shapers of children's aspirations and career trajectories. Child Development, 72, 187-206.

[3]. Blau.P. (1992).Mobility and status attainment. Contemporary Sociology, 21, 596-598.

[4]. Blau, P. \& Duncan, O. (1967). The American Educational Structure, New York: Free Press.

[5]. Boatwright, M. A., Ching, M., \& Parr, A. (1992).Factors that influence students' decisions to attend college.Journal of Instructional Psychology, 19, 79-86.

[6]. Bracey, G. W. (1992).Teacher education pipeline 111: Schools, colleges, and departments of education enrolment by race, ethnicity, and gender.(ERIC Document Reproduction Service, 369 780).

[7]. Conroy, C. A. (1997). "Predictors of occupational choice among rural youth: Implications for career education and development programming. Paper presented at the annual meeting of the American Educational Research Association, Chicago, Illinois. (ERIC Documentation Reproduction Service No. ED 408127).

[8]. Crites, J. O., \&Savickas, M. L. (1995).Revised for attitude scale and competence test CMI sourcebook. Information Systems Management, Inc., Careerware.

[9]. Davies, M., \&Kandel, D. B. (1981). Parental and peer influences on adolescents' education plans: Some further evidence. American Journal of Sociology, 87, 363-387.

[10]. Dawkins, M. P. (1989). The persistence of plans for professional careers among blacks in early adulthood.Journal of Negro Education, 58(2), $220-233$.

[11]. Demo, D. H., Small, S.A., \&Savin-Williams, R. C.(1987). Family relations and the self-esteem of adolescents and their parents.”Journal of Marriage and the Family, 49, 705-715.

[12]. Deridder, L. (1990). The impact of parents and parenting on career development.In T. N. Knoxville Comprehensive Career Development Project (Ed 325 769).

[13]. Dowdy, C. A., Carter, J. K., \& Smith, E. C. (1980).Differences in transitional needs of high school students with and without learning disabilities.Journal of Learning Disabilities,23(6).

[14]. Downey, D. B. (1995). When bigger is not better: Family size, parental resources, and children's educational performance. American Sociological Review, 60, 746-761.

[15]. Fields, B. A. (1981). Some influences upon the occupational aspirations of three white-collar ethnic groups. Adolescence, 16(63), 663-684.

[16]. Fouad, N. A., Smith, P. L., \&Enochs, L.(1997). Reliability and validity evidence for the Middle School Self-Efficacy Scale.Measurement and Evaluation in Counselling and Development,30 (1), 17-30.

[17]. Friesen, J. D. (1981). Vocational Counselling: Help from the Social Sciences. Direction (Winnipeg, MB). 
[18]. Grinstad, J. A., \& Way, W. L. (1993). The role of family in the vocational development of family and consumer education teachers: Implications for vocational education, Journal of vocational education research 18 (4) 43-80.

[19]. Grotevant, H. D., \& Cooper, C. R. (1983). The role of family communication patterns in adolescent identity and role taking. Paper presented at a meeting of the Society for Research in Child Development, Detroit, Michigan.

[20]. Hairston, J. E. (2000). How parents influence African American students' decisions to prepare for vocational teaching careers. Journal of Career and Technical Education. USA: Digital Library \& Archives.

[21]. Hensley, L. (2009). The influence of gender role and gender stereotyping on the career choice and career commitment of adolescents.Choice and career commitments of adolescents. Reviewed from http://www.samford edu/schools/artsci/scs/Hensley.html on April 4, 2009.

[22]. Hines, M. S. (1997). Factors influencing persistence among African American upperclassmen in natural science and science related majors. Paper presented at the Annual Meeting of the American Education Research Association, Chicago, Illinois.

[23]. Keller, B. K. (2004). Parental behaviours that influence adolescents' career development. University of Washington, U.S.A.

[24]. Knowles, S. (1998). "Effects of the components of parent involvement on children's educational and occupational aspirations."Unpublished doctoral dissertation, Alfred University, Alfred, New York.

[25]. Lankard, B. A. (1995). Family role in career development.ERIC Digest No. 164. ERIC/ACVE.(ED 389878 ).

[26]. Lee, C. L. (1984). An investigation of the psychosocial variables in the occupational aspirations and expectations of rural black and white adolescents: Implication for vocational education. Journal of Research and Development in Education, 17(3), 28-440.

[27]. Leong, F. T. L. (1995). Career development and vocational behaviour of racial and ethnic minorities. New Jersey: Lawrence Erlbaum Associates.

[28]. Marjoribanks, K. (1986). A longitudinal study of adolescents' aspirations as assessed by Seginer's model. Merrill-Palmer Quarterly,32, 211230 .

[29]. Marjoribanks, K. (1997). Family contexts, immediate settings, and adolescents' aspiration.Journal of Applied Developmental Psychology, $18,119-132$.

[30]. Marso, R., \&Pigge, F. (1994). Personal and family characteristics associated with reasons given by teacher candidates for becoming teachers in the 1990's: Implications for the recruitment of teachers. Paper presented at the Annual Conference of the Midwestern Educational Research Association, Chicago, Illinois, October 15, 1994. (ED 379 228).

[31]. Matope, S., \&Makotose, A.B. (2007). A study into the factors that influence female engineering students' career choice: a case study of Mutare Polytechnic, Zimbabwe. Academic Journals.

[32]. Mau, W. C., \&Bikos, L. H. (2000, spring). Educational and vocational aspirations of minority and female students: A longitudinal study. Journal of Counselling and Development, 78, 186-194.

[33]. McKay, D.R. (2009). How Do I Choose the Right Career? About.com

[34]. McNair, J., \&Rusch, F. R. (1987). Parent Survey: Identification and validation of transition issues, interchange, 7 (4). Urbana-Champagne, Illinois.: University of Illinois Transition Institute.

[35]. Michele, N. (1986). Family influences on employment and education. Overview. ERIC Digest No. 56. ERIC Clearinghouse, Colombus OH.

[36]. Middleton, E.B., \&Loughead, T. A. (1993).Parental influence on career development.An integrative framework for adolescent career counselling.Journal of Career Development 19,(3) (Spring 1993): 161-173.

[37]. Miecevole,S. (2005).Choosing the right career.Webmaster Digest, http://www.webmasterdigest.com $/$ news $/ 279 . h t m l$

[38]. Montgomery, J. (1992). Factors that influence the career aspirations of mathematically precocious females.Paper presented at the Asian Conference on Giftedness: Growing up Gifted and Talented, Taipei, Taiwan, (ED 352 267).

[39]. Mortimer, J. (1992). Influences on adolescents' vocational development.Berkeley, CA; National Center for Research in Vocational Education, (ED 352 555).

[40]. Navin, D. S. (2009). Effects of dating and parental attachment on career exploration. USA: University of New Hampshire.

[41]. Noeth, R. J., Engen, H. B., \&Noeth, P. E. (1984). Making career decisions: A self-report of factors that help high school students. Vocational Guidance Quarterly, 32(4), 240-248.

[42]. Nwadinigwe, I. P. (2002).Fundamentals of Research Methods and Ststistics. Lagos: Vitaman Educational Books and Publishers.

[43]. Olusakin, A. M., \&Ubangha, M. B. (1996).Introduction to Guidance and Counselling: A Basic Text for Tertiary Institutions. Ibadan. KSP $\&$ Depet Publishers.

[44]. Otto, L. B. (1989).How to help your child choose a career. Florida: State Department of Education. (ERIC Document Reproduction Service. $336506)$.

[45]. Parham, T. A., \& Austin, L. A. (1994). Career development and African Americans: A contextual reappraisal using the nigrescence construct. Journal of Vocational Behaviour,44(2), 139-154.

[46]. Penick, N., \&Jepsen, D. (1992). Family functioning and adolescent career development.Career Development Quarterly 40,(4) (March 1992): 208-222.

[47]. Schulenberg, J. E., Vondracek, F. W., \&Croutter, A. C.(1984).The influence of the family on vocational development.Journal of Marriage and the Family, 129-143.

[48]. Sidiropoulou-Dimakakou, D., Krassas, S. K., \&Touloumakos, A. K. (2005). The influence of school and the formation of career development of primary and secondary education students. International School Psychology Colloquium, Athens.

[49]. Splete, H., \& Freeman-George, A. (1985) Family influences on career development of young adults.Journal of Career Development 12(1) 55-64.

[50]. Simpson, D. (1996). Factors influencing the choice of law as a career by black women.Journal of Career Development, 22(3), 197-209.

[51]. Singh, et al. (1995). The effects of four components of parental involvement on eight-grade student achievement: Structural analysis of NELS-88 data. School Psychology Review,24, 299-317.

[52]. Smith, T. E. (1991). Agreement of adolescent educational expectations with perceived material and paternal educational goals. Youth and Society, 23, 155-174.

[53]. Soundar, R. (2005). Where am I going? Online edition of India's National Newspaper, India: The Hindu.

[54]. Taylor, J., Harris, M. B., \& Taylor, S. (2004). Parents Have Their Say...About Their College-Age Children's Career Decisions. Winter 2004 NACE Journal.

[55]. Trice, A. D. (1991).Stability of children's career aspirations. The Journal of Genetic Psychology, 152, 137-139.

[56]. Turner, S. L., \&Lapan, R. T. (2002). Career self-efficacy and perceptions of parent support in adolescent career development Quarterly,52, 44-55.

[57]. Wilson, P. M., \& Wilson, J. R. (1992). "Environmental influences on adolescent educational aspiration: A logistic transform model." Youth \& Society, 24, 52-70. 